\section{Recent Developments in the Syntheses of Carbazole Alkaloids}

Ulf Pindur is professor of pharmaceutical chemistry at the University of Mainz (FRG) (see Chimia $1985,39,264)$. His research interests include, above all, synthetic heterocyclic chemistry and the development of new synthetic strategies for carbazole derivatives, carbazole alkaloids, and DNA intercalating agents (e.g. annellated indoles).

$\mathrm{HCl} / \mathrm{AcOH}$, then Wolff-Kishner reduction, methylation with $\mathrm{CH}_{2} \mathrm{~N}_{2}$, and dehydrogenation $(\mathrm{Pd} / \mathrm{C})[5]$.<smiles>COC(=O)c1cc(OC)c2[nH]c3ccccc3c2c1</smiles>

Abstract. Recent developments in preparative methods for the construction of pharmacologically interesting and novel carbazole alkaloids are described. The spectrum of synthetic strategies ranges from polar (ionic) through radical to pericyclic methodologies.

\section{Introduction}

In alkaloid chemistry, interest in carbazole alkaloids has increased considerably during the past years [1-6] as a result of the expected potential of new types of pharmacologically active substances. Thus, e.g., many carbazole derivatives [7], tetrahydrocarbazoles [8], oxotetrahydrocarbazoles [9], glycozoline and mukonine isomers [10] [11], carbazomycins [12], prenylcarbazoles [2-6], nitro- and aminocarbazoles [13] as well as pyrido $[b]$ carbazoles (e.g. ellipticine derivatives and analogues) [14-19] possess anti-tumour, anti-convulsant, psychotropic, anti-inflammatory, anti-histamine, fungistatic, and antibiotic properties. Although most carbazole alkaloids are characterized by structural simplicity, selectively functionalised and/or annellated carbazoles are, in general, difficult to prepare [1-6]; hence, there is still an urgent requirement for both more selective and more efficient methods as well as for the development of novel synthetic strategies.

The present review is concerned with newer developments in the syntheses of pharmacologically attractive and, in particular, more recently isolated carbazole alkaloids. The numerous synthetic methods for the anti-tumour active pyrido $[b]$ carbazole alkaloids known to date are not included in this review since wide-ranging and informative surveys [14-19] have already been published.

The strategies employed for the synthesis of carbazole alkaloid derivatives range from polar (ionic) through radical to pericyclic reaction types.

\section{Members of the $\mathrm{C}_{13}$-Skeletal Group: Mukonine Isomers, Glycozolidal}

Mukonine (1), isolated from the stem bark of Murraya koenigii SPRENG [5], was first synthesised by a Japp-Klingemann carbazolisation reaction of a diazonium salt of 4-amino-3-hydroxybenzoic acid with 2-(hydroxymethylidene)cyclohexanone, followed by treatment with conc.
This carbazolisation modification is, in general, more flexible, more effective, and more convenient than the classical Fischer-Borsche method. Thus, analogous reactions of the diazonium salts of ortho-, meta-, and para-aminobenzoic acids with 2-(hydroxymethylidene)cyclohexanone gave rise to the three new regioisomeric analogues $\mathbf{2 a - c}$ of mukonine, respectively (Scheme l) [20].

Glycozolidal (4), recently isolated from the roots of Glycosmis pentaphylla [21], was prepared from 3 under very mild conditions and with high regioselectivity by

\section{Scheme 1}

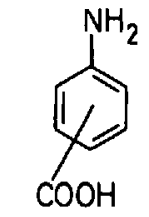

2-.3-or $4-\mathrm{COOH}$

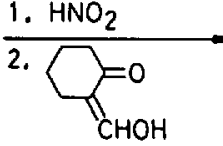

3. $\mathrm{NaOAc}, \mathrm{H}_{2} \mathrm{O}$ $\mathrm{MeOH}$<smiles>O=C1CCCCC1=NNc1cccc(C(=O)O)c1</smiles>

$(65-81 \%)$

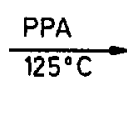

$\mathrm{COOH}$

$(66-87 \%)$

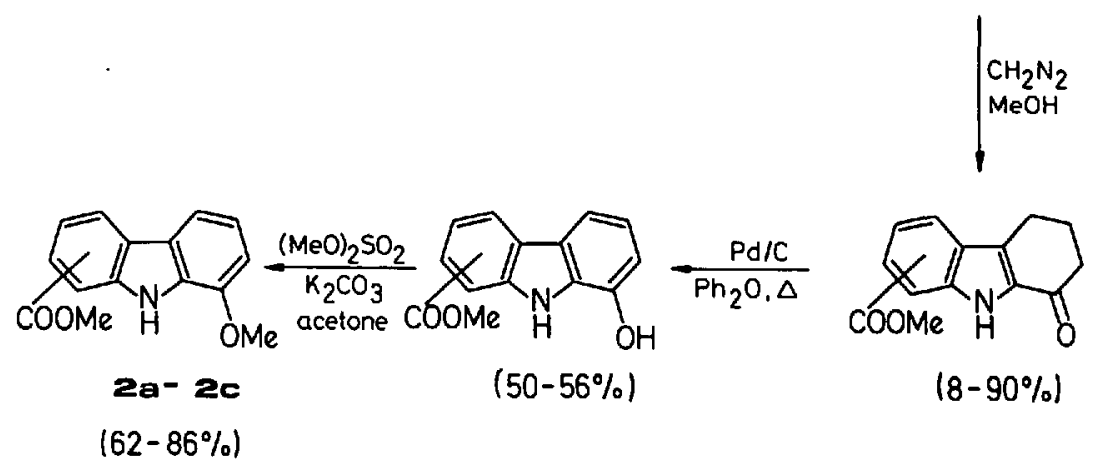

Scheme 2

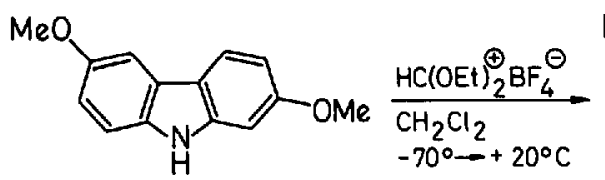

$\mathbf{3}$<smiles>COc1ccc2[nH]c3cc(OC)c(C=O)cc3c2c1</smiles>

$4 \quad(40 \%)$
* Correspondence: Prof. Dr. U. Pindur University of Mainz

Salarstrasse 21, D-6500 Mainz I 


\section{Scheme 3}<smiles>[R]c1ccc2cc(C(C)=O)[nH]c2c1</smiles>$$
\begin{array}{l|ll}
\mathbf{5} & R^{1} & R^{2} \\
\hline a & H & H \\
b & H & M e \\
c & O B n & H
\end{array}
$$<smiles>[R]c1ccc2c(c1)[nH]c1c(OC)cc([R])cc12</smiles>

$\mathrm{BF}_{3} \cdot \mathrm{MeOH}$

B $(46-59 \%)$

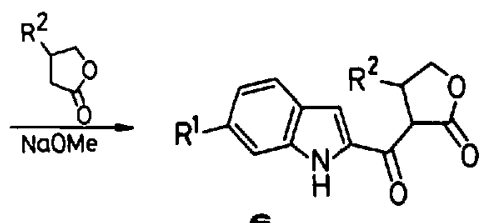

6

1. $\mathrm{H}_{2} \mathrm{O}, \mathrm{NaOH}$

2. $\mathrm{PCC}, \mathrm{NaAC}$

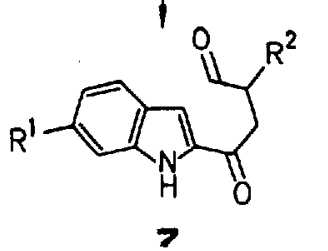

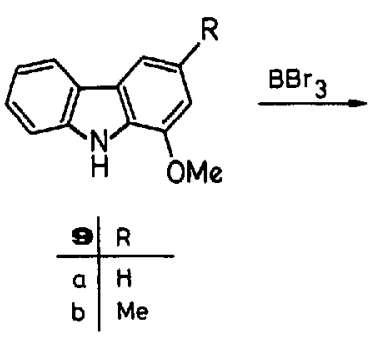

Scheme 4
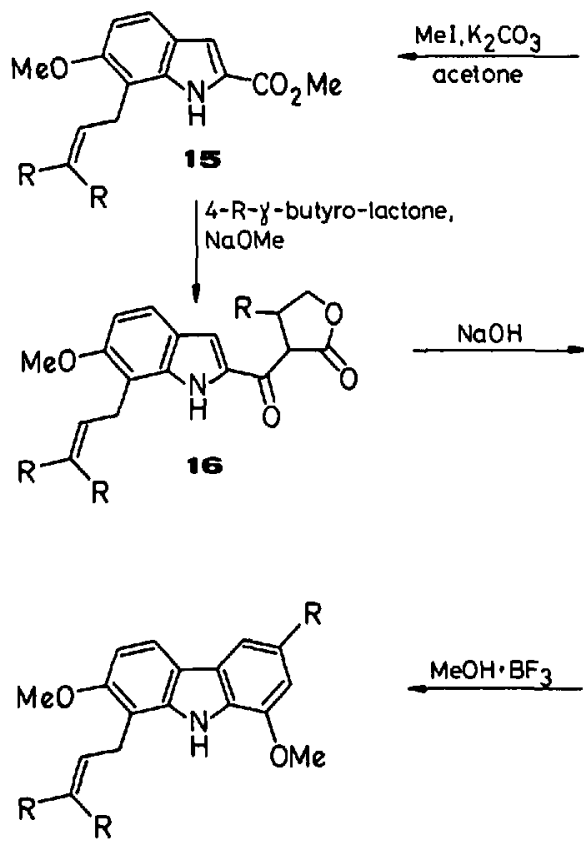

$\mathrm{MeOH} \cdot \mathrm{BF}_{3}$

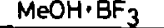

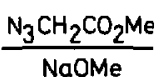

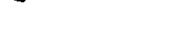

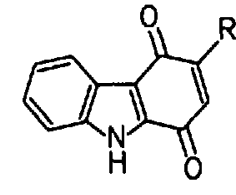

$$
\begin{array}{c|lc}
11 & \text { R } & \text { yield [\%] } \\
\hline \text { a } & \text { H } & 85 \\
\text { b } & \text { Me } & 40
\end{array}
$$

using diethoxycarbenium tetrafluoroborate as a formylating agent (Scheme 2) [22].

\section{1-Oxygenated Carbazole Alkaloids, Carbazolequinones}

New strategies for the syntheses of the carbazole alkaloids from the genus Murraya (Rutaceae) by a polar annellation route were recently developed by Moody' and coworkers [23] [24]. Thus, selectively oxygenated carbazoles were prepared by an elegant, four-step synthesis starting from the indole-2-carboxylates 5. A modification of the Claisen reaction of 5 with butyrolactones gave the lactones 6 which were hydrolysed with concomitant decarboxylation to the corresponding alcohols and then oxidised to give the aldehydes 7 (Scheme 3). The latter were cyclised to the 1 -methoxycarbazoles 8 by treatment with $\mathrm{BF}_{3} / \mathrm{MeOH}$ (or methanolic $\mathrm{HCl}$ ). The thus prepared 1-methoxycarbazoles $9 a$ and $9 \mathrm{~b}$ (murrayafoline A) were transformed to the corresponding carbazolequinones 11a and $11 b$ (murrayaquinone $A$ ) by demethylation and subsequent oxidation with Fremy's salt via the hydroxycarbazoles 10a, 10b [23].

The new carbazole alkaloid murrayaquinone $B(\mathbf{2 0})$, isolated from the root bark of Murraya euchrestifolia HAYATA, was synthesised from 12 following an analogous methodology (Scheme 4) [24]. The pathway to the 1,7-dimethoxycarbazole 19 consists of a highly regioselective Claisen rearrangement to furnish the selectively functionalised indole 14. Construction of the third ring of 19 was achieved by cyclisation of the aldehyde 18 , prepared in turn from 14 via the lactone 16. Photooxidation of 19a finally supplied murrayaquinone $B$ (20).

A more classical approach to murrayafoline $B(21)$ and murrayaquinone $B$ (20) commences with a 1-oxocarbazole precursor, consists of a four- to five-step sequence, and furnishes reasonable yields of $c a .80$ and $30 \%$, respectively [25].

In [25] another facile route to carbazole1,4-quinones was also reported (Scheme 5). The 1-hydroxycarbazoles 22 are oxidised by pyridinium chlorochromate (PCC) in $\mathrm{CH}_{2} \mathrm{Cl}_{2}$ or acetone to the quinones 23. Compound $22 \mathrm{~d}$ reacts with the acetal 24 to produce a mixture of the isomers 25 and 26. The former is then oxidised with PCC to furnish pyrayaquinone B (27), a further new pyranocarbazole alkaloid isolated from Rutaceae [26] (for further pyranocarbazoles, see also (hapt. 4).

\section{Members of the $\mathrm{C}_{18}$-Skeletal Group: Prenylcarbazoles, Pyranocarbazoles}

Alkaloids of the $C_{18}$-skeletal group possess either prenyl substitution or, in the cyclised form, pyranoannellation [6]. Among the more recently discovered mem. bers of the prenylcarbazole alkaloid series, 
Scheme 5<smiles>[Y]c1cc(O)c2[nH]c3cc([R])c([R])cc3c2c1</smiles>

22a $R^{1}=R^{2}: H$ b $R^{1}: H, R^{2}: O M e$ c $R^{1}: H, R^{2}: O A C$ d $R^{1}: H, R^{2}: O H$ e $R^{1}: A c, R^{2}: O H$

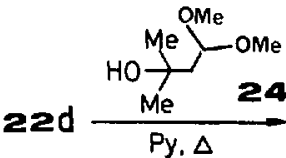<smiles>[R]C1=CC(=O)c2[nH]c3cc([R])c([R])cc3c2C1=O</smiles>

\begin{tabular}{c|c}
$\mathbf{2 3}$ & yield [\%] \\
\hline a & 40 \\
b & 30 \\
c & 25 \\
d & 25 \\
e & 30
\end{tabular}

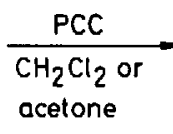

$$
\begin{array}{c|c}
\mathbf{2 3} & \text { yield [\%] } \\
\hline \text { a } & 40 \\
\text { b } & 30 \\
\text { c } & 25 \\
\text { d } & 25 \\
\text { e } & 30
\end{array}
$$

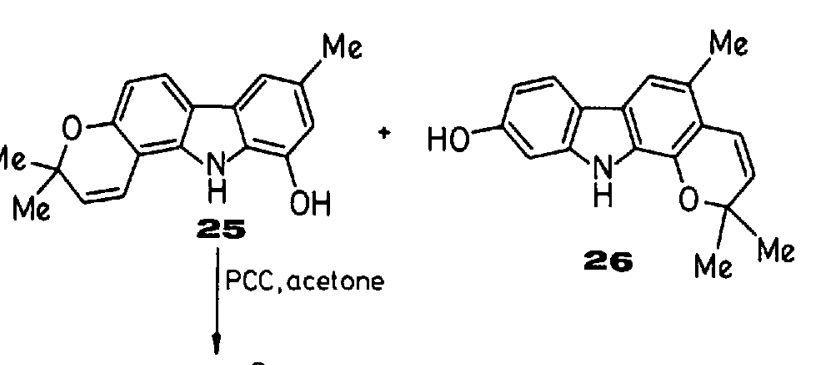

Scheme 6<smiles>COc1cc(C=O)cc2c1[nH]c1ccccc12</smiles>

$2 \boldsymbol{8}$
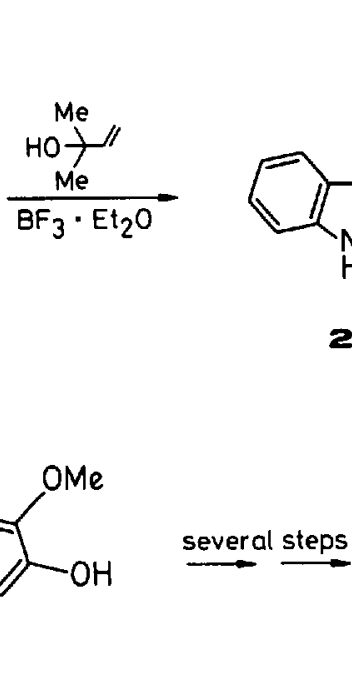

32

Scheme 9<smiles>[R]C1CC2CCC1CC21Nc2c(O)cccc21</smiles>

$$
\frac{\mathrm{CO}_{2} \mathrm{H}}{\mathrm{POCl}_{3}, \mathrm{ZnCl}_{2}}
$$

$$
\begin{aligned}
R= & 1-\mathrm{CO}_{2} \mathrm{Me} \\
& 2-\mathrm{CO}_{2} \mathrm{Me} \\
& 3-\mathrm{CO}_{2} \mathrm{Me}
\end{aligned}
$$

Scheme 7<smiles>Cc1cc2c3c([nH]c2cc1O)C(=O)CCC3</smiles><smiles>CC1(C)CCc2c(c(C=O)cc3c2[nH]c2c(O)cccc23)O1</smiles>

$\mathbf{3 1}$
The 2,2-dimethyl-2H-pyrano[a]carbazoles 36 were synthesised from the 8-hydroxycarbazoles 34 and 3-methylbut-2enoic acid via 35. Reduction of the $\mathrm{C}=\mathrm{O}$ group of 35 and subsequent elimination of $\mathrm{H}_{2} \mathrm{O}$ gave 36 (Scheme 9) [32a].

New synthetic routes to girinimbine (38) and norgirinimbine (41) were elaborated recently: the 2-hydroxy-3-methylcarbazole 37 was allowed to react with 3-chloro-3methylbut-1-yne in a one-pot procedure yielding 38 directly (Scheme 10) [32b].

Decarboxylation of 2-hydroxycarbazole-3-carboxylic acid (39) using $\mathrm{SbCl}_{3}$ as the decarboxylating agent followed by a multi-step sequence led to the linear pyranocarbazole ring system 40, norgirinimbine $(41 ; \mathbf{R}=\mathbf{H})$, and the alkaloid girinimbine (38; $\mathrm{R}=\mathrm{Me}$ ) by means of a new polar cyclisation key step (Scheme 1I) [33].

\section{Oxygenated Carbazole Alkaloids from Lower Plants}

In the last few years, applications of pericyclic methodologies with, e.g., the Diels- 
Scheme 10<smiles>Cc1cc2c(cc1O)[nH]c1ccccc12</smiles>

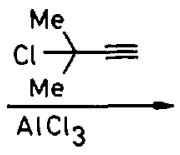

$\mathbf{3 7}$<smiles>Cc1cc2c([nH]c3ccccc32)c2c1OC(C)(C)C=C2</smiles>

$\mathbf{3 8}$

Scheme 11

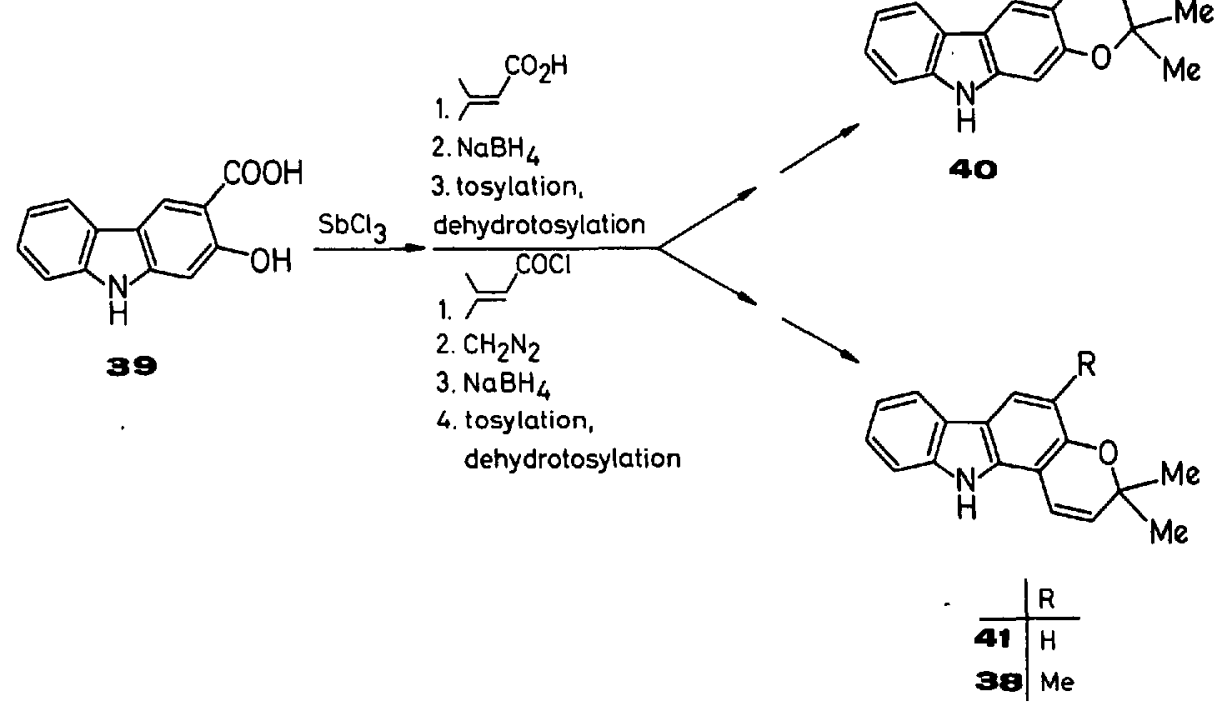

Scheme 12<smiles>[R]c1ccc2[nH]c3c(-c4ccccc4)c(C)c(OC)cc3c2c1</smiles>

\begin{tabular}{c|c}
$\mathbf{4 2}$ & $\mathrm{R}$ \\
\hline $\mathrm{a}$ & $\mathrm{H}$ \\
$\mathrm{b}$ & $\mathrm{Cl}$
\end{tabular}<smiles>[Y4]/C=C(\c1ccccc1)c1[nH]c2ccc([R])cc2c1/C=C/OC</smiles>

43

Scheme 13<smiles>CCOC(=O)OCCCC(=O)OS(=O)(=O)c1ccccc1</smiles>

44<smiles>CCC(O)(c1ccccc1)c1cc2ccccc2n1SO</smiles>

45

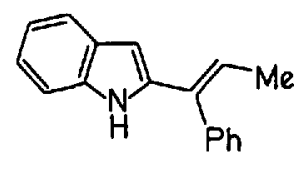

46<smiles>C/C=C(\c1ccccc1)c1[nH]c2ccccc2c1C=O</smiles>

$\mathrm{Ph}_{3} \mathrm{PCHOMe}$<smiles>C/C=C(\c1ccccc1)c1[nH]c2ccccc2c1/C=C/COC</smiles>

$\mathrm{Pd} / \mathrm{C}$<smiles>C1CCCCC1</smiles>

Alder and electrocyclic reactions as the key steps, for the construction of selectively functionalised carbazoles and/or [b]annellated indoles have increased considerably [34-37]. In this connection, the poly-substituted methoxycarbazoles such as the marine alkaloids hyellazole (42a) and 6chlorohyellazole $(\mathbf{4 2 b})$ (isolated from the blue-green alga Hyella caespitosa [38]) and carbazomycins A and B (isolated from Streptoverticillium ehimence) [39-41] represent synthetically interesting target compounds. In particular, the carbazomycins belong to the first carbazole alkaloids exhibiting antibiotic activities.

The synthesis of hyellazole (42a) and its 6-chloro derivative $\mathbf{4 2 b}$ was first achieved by an elegant $6 \pi$-electrocyclic key step involving the 2,3-divinylindoles $\mathbf{4 3}$ (Scheme 12) [42]. The preparation of $\mathbf{4 2 a}$, e.g., starts from $N$-(benzenesulphonyl)indole (44) via regiospecific lithiation and reaction with propiophenone to furnish the alcohol $\mathbf{4 5}$. Subsequent treatment with $\mathrm{NaOH}$ affords 2-(1-phenylprop-1-enyl)-indole (46) which was converted to the aldehyde 47 by means of the Vilsmeier reaction. A Wittig reaction of $\mathbf{4 7}$ gave the key compound $\mathbf{4 8}$ which, on heating with $5 \% \mathrm{Pd} / \mathrm{C}$ in xylene or decaline at higher temperatures, underwent cyclisation to produce hyellazole (42a) in $21 \%$ yield (Scheme 13). 6-Chlorohyellazole (42b) was prepared by an analogous reaction sequence in $47 \%$ yield.

Recently, a further new and more efficient access to 42a based on a novel variation of the benzannellation of indoles was described [43]. In this case, also a $6 \pi$-electrocyclic ring closure represents the key step (Scheme 14). Starting material for this procedure is the readily available 2-methoxy-3-oxo-2,3-dihydroindole (49) and the reaction sequence comprises a Wittig reaction of $\mathbf{4 9}$ with the ylide $\mathbf{5 0}$ to give the 3-(2-oxobut-3-enyl)indole 51 ( $74 \%$ yield), and treatment of $\mathbf{5 1}$ with $\mathrm{Me}_{3} \mathrm{SiI}$ in the presence of hexamethyldisilazane (HMDS) to produce the desired 3-(buta-1,3-dienyl)indole $\mathbf{5 2}$ in $80 \%$ yield. Heating of $\mathbf{5 2}$ induces an electrocyclic ring closure to form the intermediate 53 which undergoes spontaneous elimination of $\mathrm{MeOH}$ to furnish the 3-hydroxycarbazole $\mathbf{5 5}$ and its trimethylsilyl derivative 54 in 13 and $53 \%$ yield, respectively. When the silyl derivative 54 is treated with $\mathrm{Bu}_{4} \mathrm{NF}$ (TBAF) it is converted to $\mathbf{5 5}$ in $81 \%$ yield. Methylation of $\mathbf{5 5}$ with dimethyl sulphate (DMS) followed by a standard deacetylation reaction finally gives rise to $42 \mathrm{a}$ in $72 \%$ yield.

Carbazomycins and their demethoxy derivatives have also been synthesised previously. In continuation of our investigations in the field of Diels-Alder reactions of 2- and 3-vinylindoles [34-36], we have succeeded in preparing the two regioisomeric deoxycarbazomycins. Thus, 3-deoxycarbazomycin (59) is readily accessible by an in situ 3-vinylindole Diels-Alder step (Scheme 15). The thermally sufficiently stable indolyl(methoxy)methylcarbenium 
<smiles>COC1C(=O)c2ccccc2N1C(C)(C)C</smiles>

49<smiles>COc1c(CC(=O)C(C)Cc2ccccc2)c2ccccc2n1C(C)(C)C</smiles>

$\mathbf{s 1}$<smiles>COC(=Cc1c(OC)n(C(C)(C)C)c2ccccc12)C(=Cc1ccccc1)C(C)(C)C</smiles>

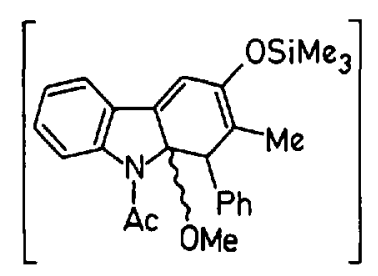

$\mathbf{5 3}$
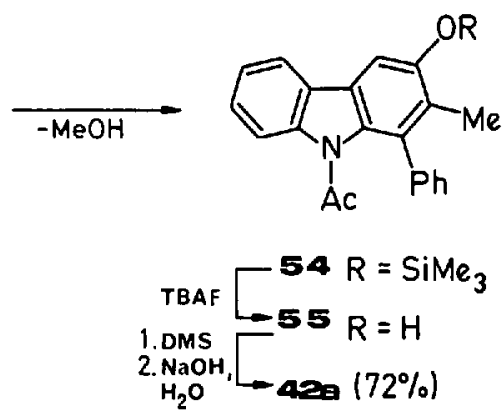

tetrafluoroborate $\mathbf{5 6}$ was deprotonated in situ to form the highly reactive 3-vinylindole 57 as an intermediate. A [4+2]-trapping reaction of 57 with dimethyl acetylenedicarboxylate and subsequent dehydrogenation gave the carbazole 58 in a one-pot procedure; finally, $\mathbf{5 8}$ was reduced to $\mathbf{5 9}$ in $28 \%$ yield [44].

The synthesis of 4-deoxycarbazomycin (62) was achieved by a related Diels-Alder methodology in which the stable $(E / Z)-2^{\prime}$ methoxy-substituted 3-vinylindole 60 was employed as a starting $4 \pi$-compound. The indole 60 was readily converted to the carbazole 61 by reaction with dimethyl acetylenedicarboxylate as a C,C-dienophile. The resultant product 61 was then transformed to the target molecule 62 by the same method as described above for the synthesis of 59 (Scheme 16) [45].

Another very selective route to 62 and the first total synthesis of carbazomycin A (68) was recently reported by Knölker and coworkers [46]. This highly effective, Feinduced $\mathrm{C}, \mathrm{C}$ - and $\mathrm{C}, \mathrm{N}$-coupling method permits a general synthesis involving only a few steps of naturally occurring carbazole derivatives that are oxygenated at $\mathrm{C}(3)$ or at $\mathrm{C}(2)$ and $\mathrm{C}(6)$ (Scheme 17). Hence, cyclisation of the preparatively easily accessible $\mathrm{Fe}$ complex under reaction conditions $A$ ) leads directly to 62 . The transformation involves the intermediate Fe complex 64 which can even be isolated when 63a is treated with $\mathrm{FeCl}_{3}$ /silica gel. Selective oxidation of compounds 63 with commercial $\mathrm{MnO}_{2}$ produces the iminoquinones 65 which undergo cyclisation when subjected to reaction conditions $A$ ) to furnish 66a and 66b. Demetallation of 66a followed by methylation of the resul-

\section{Scheme 15}<smiles>COC(=O)c1c[nH]c2ccccc12</smiles>

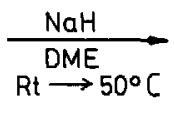<smiles>C=C(OC)c1c[nH]c2ccccc12</smiles><smiles>COc1cc(C=C(O)C([SiH3])([SiH3])[SiH3])c(C)c2[nH]c3ccccc3c12</smiles>
$59(28 \%)$<smiles>Cc1ccccc1I</smiles><smiles>COc1cc(F)c(F)c2[nH]c3ccccc3c12</smiles>

se $(11 \%)$

$E=$ COOMe

Scheme 16

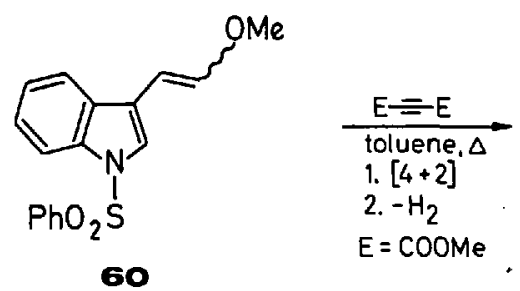<smiles>COc1cc2c3ccccc3n(S(=O)(=O)O)c2c(F)c1F</smiles>
1. $\mathrm{KOH} / \mathrm{MeOH}$ 2. $1 . \mathrm{KOHCl}_{3} / \mathrm{MeCN}$ (n-Prop) ${ }_{3} \mathrm{~N}$ 3.KOH/MeOH<smiles>COc1cc2c([nH]c3ccccc32)c(C)c1C</smiles>

Scheme 17<smiles></smiles><smiles>COc1ccc([NH3+])c(C)c1C</smiles>

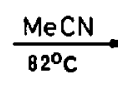<smiles>[R]C1=CC[C@@H](C)CC1(C(=O)O)C(=O)O</smiles><smiles>CCCc1cc(OC)c(C)c(C)c1N</smiles>

Gs a R:H $(95 \%)$

63 b R: OMe $(64 \%)$

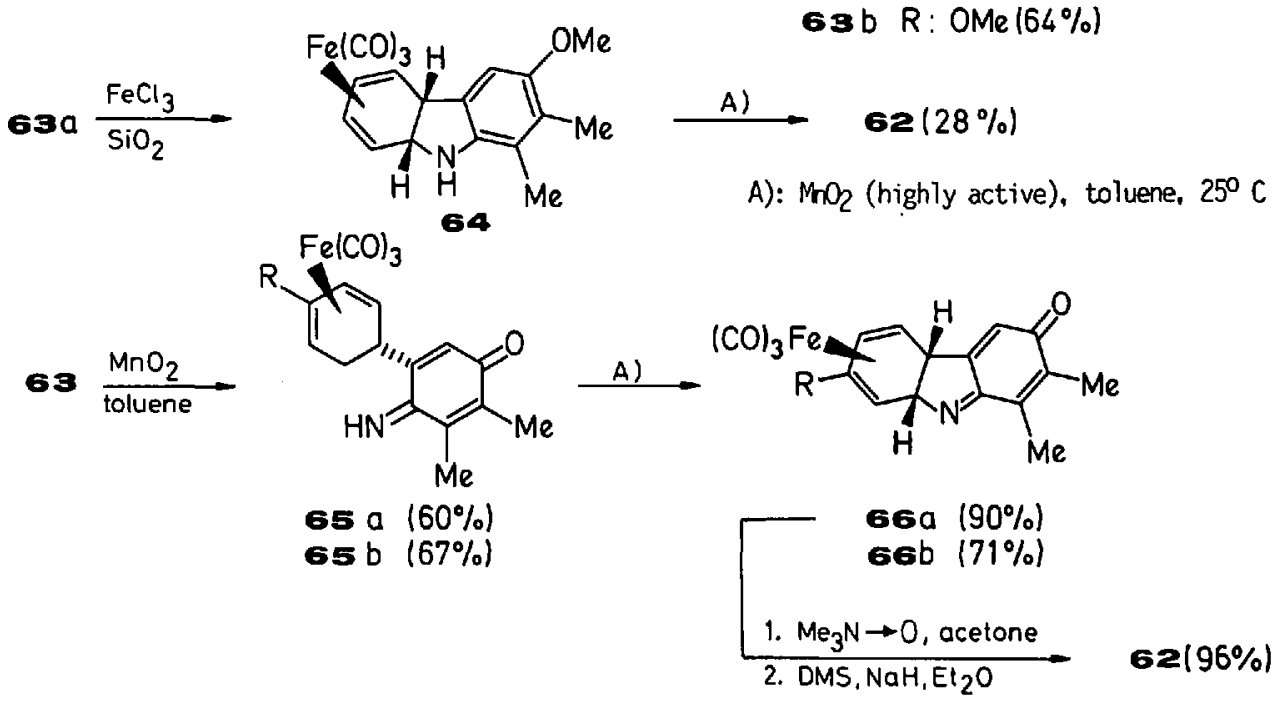


Scheme 18

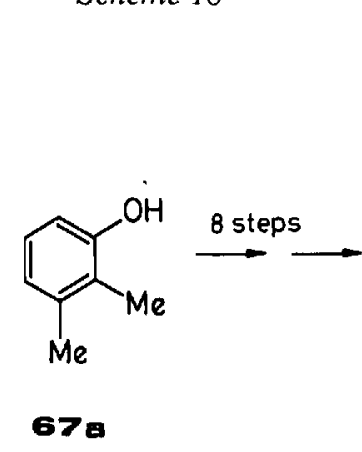

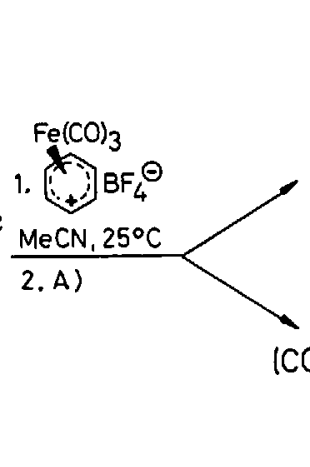<smiles>COc1c(C)c(C)c2[nH]c3ccccc3c2c1OC</smiles>

Ge $(25 \%)$

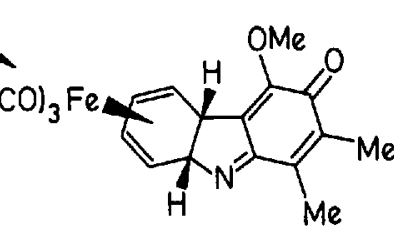

$\mathbf{6 9}(17 \%)$

Scheme 19

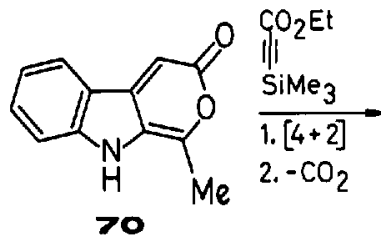<smiles>CCOC(=O)c1c(SC)cc2c([nH]c3ccccc32)c1C</smiles>

1. $\mathrm{LiAlH}_{4}$ 2. $\mathrm{Hg}(\mathrm{OAC})_{2}$ 3. $\mathrm{BH}_{3} \cdot \mathrm{THF}$

$71(53 \%)$<smiles>Cc1c(O)cc2c([nH]c3ccccc32)c1C</smiles>

Scheme 20

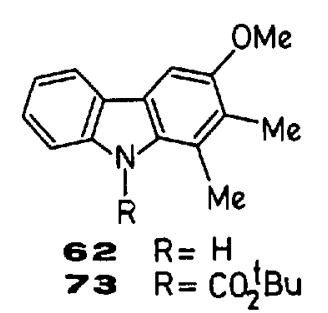<smiles>COc1c(C)c(C)c2[nH]c3ccccc3c2c1O</smiles>

tant alcohol affords 62 in $48 \%$ overall yield from 63a, thus, demonstrating the advantages of the route to aromatic carbazoles via iminoquinone cyclisations. The utility of the above methodology was further illustrated by the total synthesis of carbazomycin A (68) (Scheme 18). In addition, the by-product 69 was isolated [46].

Recently, a further new strategy for the total syntheses of carbazomycins $A$ and $B$ as well as the marine alkaloid hyellazole (42a) was described by Moody and coworkers [47]. This methodology is based on the $[4+2]$-cycloaddition of pyrano[3, 4-b]indol-3-ones; this same Diels-Alder process has since found a wide application upon hydroboration and oxidation, gave the required hydroxycarbazole 72 . Finally, the latter was easily converted to $\mathbf{6 2}$ (Scheme 19).

In a further procedure, compound 62 was converted to carbazomycin A (68) or B (75) by selective introduction of an $\mathrm{OH}$ or $\mathrm{MeO}$ group, respectively, at $\mathrm{C}(4)$ of the carbazole nucleus of 73 (Scheme 20) [47].

Here, bromination of the carbazole $\mathbf{6 2}$ with $N$-bromosuccinimide (NBS) gave the corresponding 6-bromo compound 74a, whereas bromination of the $N$-(tert-butoxycarbonyl) derivative 73 under the same conditions gave the desired 4-bromo derivative $\mathbf{7 4 b}$. Treatment of $\mathbf{7 4 b}$ with $t$ $\mathrm{BuLi}$ in THF at $-78^{\circ}$, followed by reaction of the resultant carbazolyllithium derivative with trimethyl borate, and alkaline $\mathrm{H}_{2} \mathrm{O}_{2}$ workup gave a 4-hydroxycarbazole from which removal of the $N$-protecting group to give 75 was simply achieved by heating. Methylation of 75 then yielded $\mathbf{6 8}$.

Hyellazole $\mathbf{( 4 2 a}$; $92 \%$ yield in the last step) was obtained from 1-phenylpyrano[3,4-b]indol-3-one using an analogous procedure [47]. For a further new but polar approach to selectively methylated carbazoles, see [48].

\section{Conclusions}

In addition to the more classical methods and the meanwhile well established methodologies for the synthesis of carbazole derivatives and carbazole alkaloids such as the Fischer-Borsche cyclisation, the Japp-Klingemann procedure, the GraebeUllmann method, the Pd-promoted cyclisation of diphenylamines, the cyclisation of indolyl-substituted $\beta$-keto sulphides, the free radical cyclisation of diphenylamines, and the Nenitzescu method, alternative pericyclic strategies such as, e.g., the DielsAlder reactions of vinylindoles or pyrano$[3,4-b]$ indoles as well as the $6 \pi$-electrocyclisation of selectively functionalised indole derivatives have been developed during the last few years. Complementary to these synthetic strategies, the novel, consecutive, Fe-induced C,C- and C,N-coupling method is also highly attractive for the synthesis of carbazoles. It is to be hoped - and this represents a major challenge for preparative chemistry - that, in consideration of the generally very high selectivity of pericyclic reactions, the future will bring about the syntheses of more complicated carbazole alkaloids (e.g. members of the $\mathrm{C}_{23}$-skeletal group) with more than one stereocentre. A first prerequisite for this is the achievement of an intelligent combination of polar and pericyclic reaction sequences.

The author expresses his thanks to his coworkers at the University of Mainz, Dr. L. Pfeuffer, Dr. C. Flo. Dr. H. Witzel, Dr. M. Eitel, H. Erfanian-Abdoust, Dr. H. Witzel, Dr. M. Eitel, H. Erfanian-Abdoust,
$M .-H$. Kim, R. Adam, and U. Pister for their experimental contributions and especially for their conscientious and diligent preparative work in the field of car- 
bazole chemistry. We are also grateful to the Deutsche Forschungsgemeinschaft (Bonn, Bundesrepublik Deutschland), the Fonds der Chemischen Industrie, and Boehringer Ingelheim $K G$ for generous financial support of our synthetic work in this area.

Reccived: February 20, 1990 Revised form: July 7, 1990

[1] J.A. Joule, Adv. Heterocycl. Chem. 1984, 35, 83.

[2] D. P. Chakraborty, Planta Med. 1980, 39, 97

[3] K.S. J. Stapleford, in 'Rodd's Chemistry of Carbon Compounds', Ed. M. F. Ansell, Elsevier, New York, 1985, Vol.IV, Part B, p. 71.

[4] H.P. Husson, in 'The Alkaloids', Ed. A. Brossi, Academic Press, New York, 1985, Vol. 26, p. 1 .

[5] D.P. Chakraborty, in 'Prog. Chem. Org. Nat. Products', Eds. W. Herz, H. Grisebach, and G.W Kirby, Springer Verlag, Vienna, 1977, Vol.34, p. 299

[6] P. Bhattacharyya, D.P. Chakraborty, in 'Prog. Chem. Org. Nat. Products', Eds. W. Herz, H. Grisebach, G.W. Kirby, and Ch. Tamm, Springer Verlag, Vienna, 1987, Vol. 52, p. 159

[7] W. L. Albrecht, R.W. Fleming, W.S. Horgan, G. D. Mayer, J. Med. Chem. 1974, $20,364$.

[8] A. Mooradien, A. G. Havac, P.E. Dupon, M. R Bell, A. D. Abousi, J. Med. Chem. 1975, 18, 640.

[9] N. I. Andreeva, Farmak. Toks. 1967, 36, 713 (CA. $1968,68,57793 \mathrm{r}$ ).

[10] D. P. Chakraborty, K.C. Das, B. K. Chowdhury, Trans. Bose Res. Inst. 1975, 38, I; ibid. 1975, 38, 3

[11] G. D. Shah, B. P. J. Patel, Ind. J. Chem. 1979, 188 451 .

[12] K. Sakano, K. Ishimaru, S. Nakamura, J. Antibiot. 1980, 33, 683; S. Nakamura, Trans. Bose Res. Inst. 1984, 47, 69
[13] T. Tabka, J.-F. Heron, P. Gauduchon, J.-Y. Le Talaer, J.-C. Lancelot, S. Rault, M. Robba, Eur. J. Med. Chem. 1988, 23, 119

[14] U. Pindur, Pharmaz. Uns. Zeit 1987, 16, 47.

[15] M.J.E. Hewlins, A.-M. Oliveira-Campos, P. V. R. Shannon, Synthesis 1985, 289.

[16] P. Potier, Pure Appl. Chem. 1986, 58, 737.

[17] A. Ahond, H. Fernandez, M.-J. Moore, C. Poupat, V. Sanchez, P. Potier, S. K. Kan, T. Sevenet, J. Nat. Prod. 1981, 44, 193.

[18] G.W. Gribble, M.G. Saulnier, Heterocycles 1985 $23,1277$.

[19] V. K. Kansel, P. Potier, Tetrahedron 1986, 42. 2389.

[20] D. Sowmithran, K. J.R. Prasad, Heterocycles $1986,24,711$.

[21] P. Bhattacharyya, B. K. Chowdhury, J. Nat. Prod. $1985,48,465$

[22] U. Pindur, C. Flo, unpublished results and $S y m h$. Commun. 1989, 19, 230 ?

[23] T. Martin, C.J. Moody, J. Chem. Soc., Perkin Trans. 1 1988, 235.

[24] T. Martin, C.J. Moady, J. Chem. Soc., Perkin Trans. 1 1988, 241

[25] K. Ramesh, R.S. Kapil, Indian J. Chem., Sect. B 1986, 25, 462; T.-S. Wu, T. Ohta, H. Furukawa, C.S. Kuoh, Heterocycles 1982, 20, 1267

[26] K. Ramesh, R.S. Kapil, Chem. Ind. (London) $1986,18,614$.

[27] D. Lontsi, J.F. Ayafor, B. L. Sondengam, J.D. Connolly, D.S. Rycroft, Tetrahedron Lett. 1985, 26, 4249

[28] U. Pindur, U. Pister, unpublished results,

[29] R. B. Sharma, R. S. Kapil, Chem. Ind. (London) $1980,12,158$

[30] D.P. Chakraborty, A. Islam, P. Bhattacharyya, $J$ Indian Chem. Soc. 1985, 62, 602.

[3I] S. Roy, S.K. Chatterjee, D.P. Chakraborty, $J$. Indian Chem. Soc. 1985, 62, 673 .

[32] a) D. Sowmithran, K.J. Prased, Heterocycles 1986, 24, 2195; b) P. Bhattacharyya, D.P. Cha kraborty, B.K. Chowdhury, Indian J. Chem., Sect. B 1984, 23, 849 .

[33] D. P. Chakraborty, S. Roy, A. K. Dutta, J. Indian Chem. Soc. 1987, 64, 215

[34] U. Pindur, Heterocycles 1988, 27, 1253; E. Akgün, U. Pindur, Chimia 1985, 39, 264

[35] L. Pfeuffer, U. Pindur, Helv. Chim. Acta 1987, 70 1419.

[36] L. Pfeuffer, U. Pindur, Helv. Chim. Acta 1988, 7I, 467; U. Pindur, M.-H. Kim, Tetrahedron 1989, 45 , 6427; U. Pindur, M.-H. Kim, M. Eitel, Terrahedron Lett. 1990, 3l, 1551.

[37] U. Pindur, H. Erfanian-Abdoust, Chem. Rev $1989,89,1681$.

[38] J.H. Cardelina, M.P. Kirkup, R. E. Moore, J.S Mynderse, K. Seff, C. J. Simmons, Tetrahedron Lett. 1979, 4915.

[39] K. Sakano, S. Nakamura, J. Antibiot. 1980, 33 961 .

40] M. Kancda, K. Sakano, S. Nakamura, Y. Kushi, Y. litaka, Heterocycles 1981, 15, 993.

[4I] T. Naid, T. Kitahara, M. Kaneda, S. Nakamura, J. Antibiot. 1987, 40, 157

[42] S. Kano, E. Sugino, S. Shibuya, S. Hibino, J. Org Chem. 1981, 46, 3856.

[43] T. Kawasaki, Y. Nonaka, K. Sakamoto, J. Chem. Soc., Chem. Commun. 1989, 43.

[44] U. Pindur, L. Pfeuffer, Tetrahedron Lett. 1987, 28 3079.

[45] U. Pindur, L. Pfeuffer, Heterocycles 1987, 26, 325

[46] H.-J. Knölker, M. Bauermeister, D. Bläser, R. Boese, J.-B. Pannek, Angew. Chem. 1989, 101 225; ibid. Int. Ed. 1989, 28, 225; H.-J. Knölker. M. Baumeister, J. Chem. Soc, Chem. Commun. 1989 1468.

[47] C.J. Moody, P. Shah, J. Chem. Soc., Perkin Trans. $/ 1989,376$

[48] J. Bergman, B. Pelcman, Tetrahedron 1988, 44, 5215.

\section{Matrix-Assisted Laser Desorption and Ionization Mass Spectrometry and Its Applications in Chemistry}

\section{Introduction}

Since its development in 1988 by Karas and Hillenkamp [1] matrix-assisted laser desorption mass spectrometry (LDI-MS) has received an immensely growing interest. With the fast development of peptide synthesis and genetic engineering in particular, the need for a method which allows to determine the molecular weight of proteins and polypeptides with high accuracy and sensitivity has increased simultaneously. The LDI-MS has the potential to fulfill these needs. The LDI-MS can be used as well to solve analytical and mass-spectrometric problems for other interesting chemical species besides proteins due to its high sensitivity and its low selectivity. The method allows to desorb and ionize large molecules up to $200 \mathrm{kDa}$ and to determine the molecular weight with as little as $100 \mathrm{fmol}$ sample. Thus, the sensitivity of LDI is comparable with other analytical methods like RP HPLC. The method has a dynamic range of at least 1:100 which al-
Abstract. The present paper gives a summary of the potentialities of matrix-assisted laser desorption and ionization mass spectrometry (LDI-MS). Mass spectrometric information on different chemical and biochemical species are obtained with LDI-MS. Sulfonic acids, polysaccharides, oligonucleotides, and peptides were measured as negatively or positively charged ions in a time-of-flight mass spectrometer (TOF-MS). The amount of sample for a measurement lies between $50 \mathrm{pmol}$ and $100 \mathrm{fmol}$ and is, thus, comparable with other analytical and mass spectrometric methods. The large mass range from 0.6 $\mathrm{kDa}$ up to $200 \mathrm{kDa}$ is accessible with LDI-MS. Molecular-weight determination can be done with an accuracy of less than $0.2 \%$. Comparison with RP HPLC reveals the power of LDI-MS as an analytical tool.
* Correspondence: Dr. K.O. Börnsen

Central Analytical Department

Ciba-Geigy Ltd.

$\mathrm{CH}-4002$ Basel 